\title{
Analysis the Implementation of Early Mobilization, Breast Care and Oxytosin Massage on Production ASI in Primipara Post Partum Mother in Dongko Health Centre Trenggalek City
}

\author{
Enggar Wahyu Anggraeni', \\ Indasah $^{2}$, Koesnadi $^{2}$ \\ ${ }^{1}$ Student Graduate Program in \\ Health Sciences Institut Ilmu \\ Kesehatan STRADA Indonesia \\ ${ }^{2}$ Lecturers of the Postgraduate \\ Program in Health Sciences Institut \\ Ilmu Kesehatan STRADA \\ Indonesia \\ Email: \\ enggarwahyu04@gmail.com
}

Received: October 12, 2019

Accepted : February 13, 2020

Published : May 12, 2020

\begin{abstract}
The aim of the study was to analyze the effect of early mobilization, breast care and oxytocin massage on breast milk production in post partum mothers at the Dongko Health Center in Trenggalek Regency in 2018. The study was conducted at the Dongko Health Center in Trenggalek Regency on 12 November 2018 -8 December 2018. The type of association analytic research was the one group pre test - post test design model. Independent variables were early mobilization research, breast care and oxytocin massage, the dependent variable of breast milk expenditure in post partum mothers. The study population was all post partum mothers at the Dongko Health Center in Trenggalek Regency. The sampling technique used simple random sampling with a sample of 24 people. Data were analyzed using the Wilcoxon signed rank test and one way ANOVA. The results showed: 6 respondents $(100 \%)$ before the early mobilization of ASI production was lacking, and after them normal, 6 respondents $(100 \%)$ before breast care had less milk production and after them normal, 6 respondents (100\%) before oxytocin massage had less milk production, and after them was normal. There is an effect of early mobilization, breast care and oxytocin massage on breast milk expenditure in post partum mothers where the value of $p=$ 0,000 where $\mathrm{p}<\alpha(0.05)$. Massage oxytocin has the highest mean value. This shows that the highest increase in breast milk expenditure in the Dongko Health Center in Trenggalek Regency is the oxytocin massage treatment. By doing oxytocin massage, the oxytocin reflex will increase and will work with the prolactin reflex in the formation of sufficient milk. Oxytocin will cause the muscle cells surrounding the milk making channel to contract or contract so that the milk is pushed out of the milk production channel and flows ready to be sucked by the baby.
\end{abstract}

Keywords: Early mobilization, breast care, oxytosin massage, breast milk production 


\section{INTRODUCTION}

In the process of breastfeeding, there are often problems that occur during breastfeeding such as swollen breasts, mastitis, drowning nipples, breast milk has not come out and improper breastfeeding techniques affect the failure of breastfeeding (Roesli, 2013 ). In post partum mothers often because the pain experienced after giving birth makes the mother lazy to breastfeed the baby, this can cause the production of breast milk to be not smooth due to lack of stimulation in the breast so that the cycle of oxytocin is not smooth and causes breast milk not to come out (Roesli, 2013).

Based on data in East Java, it was found that the coverage of infants who were exclusively breastfed in East Java in 2014 was 72.89\% (attachment to health profile data table 39). The coverage increased compared to 2013 (68.48\%) (East Java Health Office, 2015). In Trenggalek Regency the presentation of infants who were given exclusive breastfeeding during 2015 amounted to $68.94 \%$ of the total number of babies 0-6 months, namely as many as 10,326 people ( Trenggalek Health Office, 2017 ). Based on the above data, exclusive breastfeeding coverage for infants has not been reached $100 \%$. The results of the preliminary survey conducted on September 17, 2018 at the Dongko Health Center, revealed that of the 10 post partum mothers only 6 mothers who took exclusive breastfeeding and 4 gave formula milk to their babies. This can occur because of problems in breastfeeding such as the lack of smooth production of breast milk in the mother so that the needs of breast milk are not fulfilled and at the end of the day is given additional breast milk such as formula milk.

The impact of breast milk production that is not smooth in the mother can cause breast distension, mastitis, and low fulfillment of nutritional needs in infants. While the impact on the baby, the low fulfillment of the nutritional needs of the baby, can affect the child's growth process and unmet needs, namely: feeling safe, the warmth of the mother's arms, soft touch (Saleha, 2015).

Less milk production can be increased by pharmacology or non-pharmacology. Pharmacology is to use drugs and use of special formula milk for nursing mothers. The non-pharmacology can be done with a diet with balanced nutrition for nursing mothers, early mobilization, with oxytocin massage and breast care (Ministry of Health, 2016).

Solutions to increase breast milk production in a non-pharmacological way can be done by early mobilization. Early mobilization is a policy to immediately guide the client out of bed and guide him as soon as possible to walk. Clients are allowed to get out of bed in 24-48 hours post partum (Diah, 2013). The benefits of early mobilization are launching lochea's expenditure, reducing puerperium infection, accelerating the involutionof uterine devices, facilitating the functioning of gastrointestinal devices and urinary devices, increasing the smooth circulation of the blood so as to speed up the function of breast milk and metabolic waste. Factors that affect postpartum women are not early mobilization because the mother is still tired, pain in the birth canal area, besides that the mother does not know the importance of early mobilization, goals and benefits, so thatpostpartum mothers can lose themselves if they do not carry out early mobilization. uterine involution is not good so that the remaining blood cannot and causes infection (Manuaba, 2013).

Also with oxytocin massage is massage along the vertebre bone to the fifth-sixth bone bone and is an attempt to stimulate the hormone prolactin and oxytocin after childbirth (Roesli, 2013). Oxytocin massage is done to stimulate oxytocin reflexes or let down reflexes. Breastfeeding mothers who do the oxytocin massage will feel relaxed so that oxytocin will increase. Oxytocin will cause the muscle cells surrounding the milk-making channel to contract or contract so that the milk is pushed out of the milk production channel and flows ready to be sucked by the baby. In addition to oxytocin massage also provides comfort to the mother, reduces swelling, reduces blockage of milk, stimulates the release of the hormone oxytocin, maintains breast milk production when the mother and baby are sick (Ministry of Health, 2016).

In addition to early mobilization and oxytocin massage techniques to facilitate breastfeeding, it can also be overcome by providing breast care, namely breast care, which is done to facilitate breastfeeding and avoid difficulties during breastfeeding by doing massage (Welfrd, 2015).

Breast care is an attempt to stimulate the secretion of the hormone oxytocin to produce breast milk as early as possible and play an important role in dealing with the problem of breastfeeding. The technique of massage and stimulation of the nipples performed on breast care is an exercise such as the effect of infant suction as a trigger for breastfeeding (Tamboyang, 20 15). Indications for breast care are performed on breasts that do not experience abnormalities and those with abnormalities such as 
swelling, blisters, and inverted nipples (nipples not prominent) (Suryono-Roischa Dyah Pramitasia 2014).

The role of nurses is needed in providing nursing care to mothers in the breastfeeding process by providing counseling about breastfeeding (providing anticipatory guidance for potential problems such as debriefing, pain, reduced milk production, feelings of disappointment, depression, guilt (Nanda, 2016).

From the background above, a study was carried out with the title "The Effect of Early Mobilization, Breast Care and Oxytocin Massage on the Production of A SI in Post Partum Mothers in the Dongko Health Center in Trenggalek Regency in 2018". This research ia aim to analyze the influence of early mobilization, breast care and massage oxytocin to Production A SI on post partum mothers at health centers Trenggalek Dongko 2018

\section{METHODS}

This type of research is True Experimental Design using the one group pre test - post test design model. The population was all post partum mothers at the Dongko Health Center in Trenggalek Regency in 2018 on average each month as many as 50 post partum mothers. The sampling technique uses simple random sampling with a sample size of 24 people.

In this study, the independent variable is the early mobilization, breast care and massage oxytocin and the dependent variable of breast milk expenditure in post partum mothers. The research instrument used a checklist sheet. The results of data collection were analyzed by the Wilcoxon signed rank test and one way ANOVA.

\section{RESULTS}

Characteristics of Respondents

Table 1 Characteristics of respondents

\begin{tabular}{lcc}
\hline Characteristics & N & \% \\
\hline Age & 1 & 4.2 \\
$<20$ year & 22 & 91.7 \\
$20-35$ years & 1 & 4.2 \\
$>$ 35 years old & 5 & \\
\hline Education & 5 & 20.8 \\
Elementary, middle school & 17 & 70.8 \\
High school & 1 & 8.3 \\
PT & 10 & 41.7 \\
\hline Work & 6 & 25 \\
IRT & 6 & 25 \\
entrepreneur & 2 & 8.3 \\
Private employees & & \\
Civil servants & & \\
\hline
\end{tabular}

Data source: Data Analysis Results

Variable characteristics

Table 2 Breast milk production

\begin{tabular}{lcc}
\hline Breast milk production & N & \% \\
\hline Before Early Mobilization & & 100 \\
Less & 6 & 0 \\
Normal & 0 & 0 \\
More & 0 & 0 \\
\hline After Early Mobilization & & 100 \\
Less & 0 & 0 \\
Normal & 6 & 0 \\
\hline More & 0
\end{tabular}

Before breast care 


\begin{tabular}{lcc}
\hline Less & 6 & 100 \\
Normal & 0 & 0 \\
More & 0 & 0 \\
\hline After Breast Care & & 0 \\
Less & 0 & 100 \\
Normal & 6 & 0 \\
More & 0 & 100 \\
\hline Before Oxytocin Massage & & 0 \\
Less & 6 & 0 \\
Normal & 0 & 0 \\
More & 0 & 100 \\
\hline After Oxytocin Massage & & 0 \\
Less & 0 & \\
Normal & 6 & 0 \\
More & 0 & \\
\hline
\end{tabular}

Data source: Data Analysis Results

Inter-Variable Cross Tabulation

Table 3 Tabulation of ASI Expenditures Before and After Early Mobilization

\begin{tabular}{ccccccccc}
\hline \multirow{2}{*}{$\begin{array}{c}\text { Before } \\
\text { breastfeeding }\end{array}$} & \multicolumn{9}{c}{ Less } & \multicolumn{9}{c}{ Normal } & \multicolumn{3}{c}{ More } & \multicolumn{2}{c}{ Total } \\
\hline & $\mathrm{N}$ & $\mathrm{F}$ & $\mathrm{N}$ & $\mathrm{F}$ & $\mathrm{N}$ & $\mathrm{F}$ & $\mathrm{N}$ & $\mathrm{F}$ \\
\hline Less & 0 & 0 & 6 & 100 & 0 & 0 & 6 & 00 \\
\hline Normal & 0 & 0 & 0 & 0 & 0 & 0 & 0 & 0 \\
\hline More & 0 & 0 & 0 & 0 & 0 & 0 & 0 & 0 \\
\hline Total & 0 & 0 & 6 & 100 & 0 & 0 & 6 & 100 \\
\hline
\end{tabular}

Based on table 3 shows that of 6 respondents, all respondents were as many as 6 respondents $(100 \%)$ before the early mobilization of their breastfeeding was lacking and after early mobilization the expenditure of ASI was normal.

Table 4 Tabulation of breastfeeding before and after breast care

\begin{tabular}{ccccccccc}
\hline \multirow{2}{*}{$\begin{array}{c}\text { Before } \\
\text { breastfeeding }\end{array}$} & \multicolumn{9}{c}{ Less } & \multicolumn{2}{c}{ Normal } & \multicolumn{3}{c}{ More } & \multicolumn{2}{c}{ Total } \\
\hline & $\mathrm{N}$ & $\mathrm{F}$ & $\mathrm{N}$ & $\mathrm{F}$ & $\mathrm{N}$ & $\mathrm{F}$ & $\mathrm{N}$ & $\mathrm{F}$ \\
\hline Less & 0 & 0 & 6 & 100 & 0 & 0 & 6 & 00 \\
\hline Normal & 0 & 0 & 0 & 0 & 0 & 0 & 0 & 0 \\
\hline More & 0 & 0 & 0 & 0 & 0 & 0 & 0 & 0 \\
\hline Total & 0 & 0 & 6 & 100 & 0 & 0 & 6 & 100 \\
\hline
\end{tabular}

Based on table 4 shows that of 6 respondents, all respondents were as many as 6 respondents ( $100 \%$ ) before breast care for breastfeeding was lacking and after breast care the breast milk was released normally.

Table 5 Tabulation of Breast Milk Expenditures Before and After Oxytocin Massage

\begin{tabular}{|c|c|c|c|c|c|c|c|c|}
\hline \multirow{3}{*}{$\begin{array}{c}\text { Before } \\
\text { breastfeeding }\end{array}$} & \multicolumn{6}{|c|}{ After breastfeeding } & \multirow{2}{*}{\multicolumn{2}{|c|}{ Total }} \\
\hline & \multicolumn{2}{|c|}{ Less } & \multicolumn{2}{|c|}{ Normal } & \multicolumn{2}{|c|}{ More } & & \\
\hline & $\mathrm{N}$ & $\mathrm{F}$ & $\mathrm{N}$ & $\mathrm{F}$ & $\mathrm{N}$ & $\mathrm{F}$ & $\mathrm{N}$ & $\mathrm{F}$ \\
\hline Less & 0 & 0 & 6 & 100 & 0 & 0 & 6 & 00 \\
\hline Normal & 0 & 0 & 0 & 0 & 0 & 0 & 0 & 0 \\
\hline More & 0 & 0 & 0 & 0 & 0 & 0 & 0 & 0 \\
\hline Total & 0 & 0 & 6 & 100 & 0 & 0 & 6 & 100 \\
\hline
\end{tabular}


Based on table 5, it shows that from 6 respondents, all respondents, as many as 6 respondents ( $100 \%$ ) before the massage of oxytocin, their milk output was lacking and after massage oxytocin the milk output was normal.

Statistical Test Results

Table 6 Statistical Test Results

\begin{tabular}{lcc}
\multicolumn{1}{c}{ Variable } & Analysis & $\mathrm{P}$ \\
\hline Expenditures for breast milk before * after Early Mobilization & Paired T Test & 0,000 \\
\hline Breastfeeding before * after breast care & Paired T Test & 0,000 \\
\hline Breastfeeding before * after oxytocin massage & Paired T Test & 0,000 \\
\hline Expenditures for breast milk before * after treatment & Paired T Test & 0.015 \\
\hline
\end{tabular}

Source: primary research data

Based on table 6 shows the results of paired t test between breastfeeding before and after early mobilization, breast care and oxitocyn massage obtained $p=0,000$ where $p<\alpha(0.05)$ so that $H O$ is rejected which means that there is an effect of early mobilization, breast care and oxiocyn massage on breast milk expenditure in post partum mothers at Dongko Health Center Trenggalek Regency . The changes in breastfeeding expenditures, namely before the initial mobilization, breast care and oxiocyn massage is carried out, the breastfeeding is less and after early mobilization, breast care and oxiocyn massage the breastfeeding is normal.

Table 8 Duncan Post Hoc Test Results

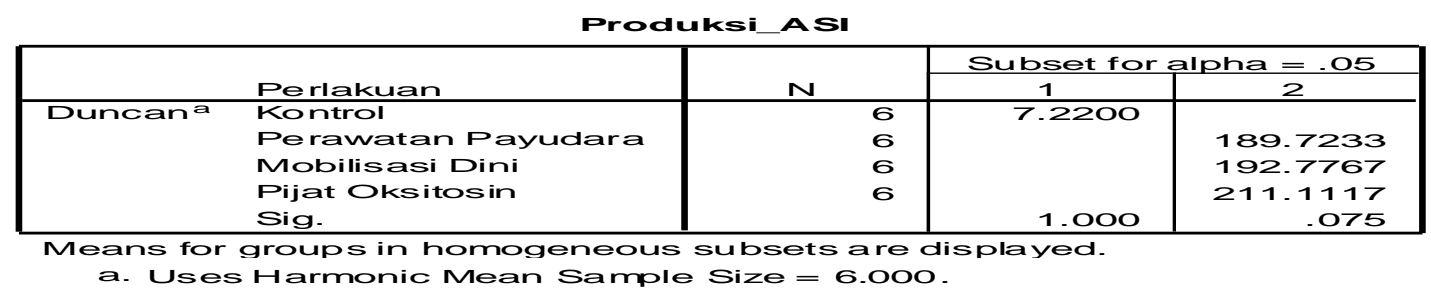

Based on the table above it is known that seen from the harmonic mean values produced between treatment groups and control groups are in different subset columns. This shows that there are significant differences between the treatment and control groups. And in the treatment group showed that oxytocin massage had the highest mean value. This shows that the highest increase in ASI expenditure is oxytocin massage treatment

\section{DISCUSSION}

The influence of early mobilization on breast milk production in post partum mothers at the Dongko Health Center in Trenggalek Regency

The results showed that from 6 respondents, all respondents were as many as 6 respondents ( $100 \%$ ) prior to early mobilization of breastfeeding were lacking and after early mobilization the expenditure of breast milk was normal. $\mathrm{H}$ acyl test paired t test between expenditure breastfeeding before to after the early mobilization was obtained $p=0.000$ where $p<\alpha(0.05)$ so $H O$ is rejected, which means that there is the influence of early mobilization against ASI expenditure on post partum mothers at health centers Trenggalek Dongko. The changes in breastfeeding expenditures, namely before the initial mobilization is carried out, the breastfeeding isless and after early mobilization, the breastfeeding is normal.

Early mobilization is an action taken by health professionals to help patients get out of their beds and guide them as early as possible to walk (Dewi, 2013). Early mobilization has several advantages, which can expedite the release of lochea, reduce post partum infection, accelerate involution of uterine devices, facilitate the functioning of gastrointestinal devices and urinary devices, improve blood circulation, acceleratebreastfeeding and improve the functioning of the mother (Dewi, 2013). Furthermore, according to Dewi (2013) by doing post partum early mobilization can facilitate the release of blood and remaining placenta, uterine contractions are good so that the process of 
returning the uterus to its original form goes well and in addition mobilization can increase the smooth circulation of blood so that the function of breast milk and metabolic waste.

Early mobilization is a policy to immediately guide the client out of bed and guide him as soon as possible to walk. Clients are allowed to get out of bed in 24-48 hours post partum (Diah, 2013). Factors affecting postpartum mothers not early mobilization because the mother was weary, pain in the region of the birth canal, other than that the mother did not know about the importance of early mobilization, objectives, benefits andhow to implement it, so postpartum mothers can lose yourself when not mobilized early as causing process uterine involution is not good so that the remaining blood cannot and causes infection (Manuaba, 2013).

Based on the facts, theories and studies above show that early mobilization can have a significant effect on increasing breast milk production in primiparous puerperal mothers. This is because that by doing early mobilization the blood circulation will be more smoothly including the circulation of blood in the breast channel so that the production of ASI will be more smoothly.

\section{The influence of breast care on breast milk production in post partum mothers at the Dongko Health Center in Trenggalek Regency}

The results of the study showed that from 6 respondents, all respondents were as many as 6 respondents $(100 \%)$ before breast care, their breastfeeding was less and after treatment of breast, the breast milk was normal. The results of the paired t test between breastfeeding before oxytocin massage were $p=0,000$ where $p<\alpha(0.05)$ so that $H O$ was rejected which means that there was an effect of oxytocin massage on breastfeeding in post partum mothers at Dongko Puskesmas Trenggalek Regency . As for changes in breast milk expenditure, prior to the massage of oxytocin, the release of breastmilk was lacking and after massage oxytocin, the milk removal was normal.

Breast care is an attempt to stimulate the secretion of the hormone oxytocin to produce breast milk as early as possible and play an important role in dealing with the problem of breastfeeding. The technique of massage and stimulation to the teats of milk were carried out on breast care a baby sucking effect such exercise as a trigger spending ASI (Tamboyang, 2013).

The best way to guarantee the release of breast milk is to make sure that every time you breastfeed your breasts are completely empty, because emptying the breasts at a certain time stimulates the gland of the breasts to make more milk. The causes of the breasts will be sucked out, among others, caused by a weak baby, blotchy nipples, excessive milk production. In case the breasts have not been completely empty after breastfeeding, they usually have to be emptied by pumping or sorting. Squeezed milk may be given to babies (Indiarti, 2014).

Movement in breast care is beneficial to smooth out the reflexes of breast milk. And there is nothing wrong with cleaning the nipples with warm water after each bath to maintain cleanliness and avoid using soap that can make the nipple dry, because if it is dry it causes the nipple layer to peel and pain arises when breastfeeding. Last but not least, preventing dams in the breast (Pramitasari and Saryono, 2013).

Based on the facts, theories and studies above show that breast care can have a significant effect on increasing milk production in primiparous puerperal mothers. This is because that by doing breast care it willstimulate the milk glands and be able to find out breast abnormalities so that efforts can be made to overcome them. Thus the production of breast milk will be more smoothly.

\section{The effect of oxytocin massage on breast milk production in post partum mothers at the Dongko Health Center in Trenggalek Regency}

The results of the study showed that from 6 respondents, all respondents, as many as 6 respondents (100\%) before the massage of oxytocin, their milk output was less and after massage oxytocin was normal. The results of paired $t$ test between breastfeeding before and after breast care were $p=0,000$ where $p<\alpha(0,05)$ so that $H 0$ was rejected which means that there was an effect of breast care on breastfeeding in post partum mothers at Dongko Puskesmas in Trenggalek Regency . As for changes in breastfeeding expenditures, namely before the breast care is removed, the milk is less and after the breast care is done the breast milk is normal.

Reflex flow or let down reflex after being produced by the source of milk maker, breast milk will be released from the source of milk maker and flowed into the milk ducts. This breastfeeding occurs 
because smooth muscle cells around the breast gland constrict to squeeze the milk out. The cause of the muscles shrinking is a hormone called oxytocin.

Baby suction stimulation through nerve fibers spurs posterior pituitary to release the hormone oxytocin in the blood. Oxytocin stimulates the myoepithel cells that surround the alveoli and ducts to contract, thereby flowing breast milk from the alveoli to the ductus towards the sinuses and nipples. Thus frequent breastfeeding is important for emptying the breast so that engorgement does not occur (swollen breasts), but it actually facilitates the flow of breast milk.

In addition, oxytocin also plays a role in spurring uterine muscle contractions, thereby accelerating the release of the placenta and reducing bleeding after childbirth. The important thing is that the baby will not get enough milk if it only relies on breast milk reflex or prolactin reflexes. He must be helped by oxytocin reflexes. If this reflex does not work, the baby will not get adequate milk, even though the milk production is sufficient.

Oxytocin reflexes are more complicated than the prolactin reflex. A mother's thoughts, feelings and sensations will greatly affect this reflex. Mother's feelings can increase and also inhibit oxytocin expenditure. This hormone will cause the muscle cells surrounding the milk making channel to contract or contract so that the milk is pushed out of the milk production channel and flows ready to be sucked by the baby.

Oxytocin massage is one solution to overcome the inability of breast milk production. Oxytocin massage is massage the whole spine (vertebrae) bone until costae fifth, sixth and an attempt to stimulate the hormones prolactin and oxytocin after delivery (Yohmi \& Roesli, 2013).

Based on the facts, theories and studies above show that oxytocin massage can have a significant effect on increasing milk production in primiparous puerperal mothers. This is because the massage of oxytocin willincrease the reflex of oxytocin and will work together with the prolactin reflex in the formation of sufficient milk.

\section{The dominant influence is between early mobilization, oxytocin massage and breast care on breast milk production}

Based on the Duncan post hoc test, it is known that seen from the harmonic mean values produced between the treatment groups and the control groups are in different subset columns. This shows that there are significant differences between the treatment and control groups. And in the treatment group showed that oxytocin massage had the highest mean value. This shows that the highest increase in ASI expenditure is oxytocin massage treatment.

The level of oxytocin is massage along the vertebre bone to the fifth-sixth bone bone and is an attempt to stimulate the hormone prolactin and oxytocin after childbirth (Roesli, 2013 ). Oxytocin massage is done to stimulate oxytocin reflexes or let down reflexes. Breastfeeding mothers who do the oxytocin massage will feel relaxed so that oxytocin will increase. Oxytocin will cause the muscle cells surrounding the milk-making channel to contract or contract so that the milk is pushed out of the milk production channel and flows ready to be sucked by the baby. In addition to oxytocin massage also provides comfort to the mother, reduces swelling, reduces blockage of milk, stimulates the release of the hormone oxytocin, maintains breast milk production when the mother and baby are sick (Ministry of Health, 2016).

Based on the facts, theories and studies above show that oxytocin massage has the most significant effect in increasing breast milk production in primiparous puerperal mothers . This is because the massage of oxytocin will increase the reflex of oxytocin and will work together with the prolactin reflex in the formation of sufficient milk. Oxytocin will cause the muscle cells surrounding the milk-making channel to contract or contract so that the milk is pushed out of the milk production channel and flows ready to be sucked by the baby.

\section{CONCLUSIONS}

$P$ roduction breastfeeding on postpartum mother in Puskesmas Dongko Trenggalek before early mobilization wholly ie 6 respondents (100\%) of its milk production less. 
P roduction breastfeeding on postpartum mother in Puskesmas Dongko Trenggalek before breast care entirely, namely 6 respondents (100\%) of its milk production less.

$P$ roduction breastfeeding on postpartum mothers at health centers before massage Trenggalek Dongko oxytocin wholly ie 6 respondents (100\%) of its milk production less.

$P$ roduction breastfeeding on postpartum mothers at health centers Trenggalek Dongko after early mobilization wholly ie 6 respondents (100\%) of its milk production to normal.

$P$ roduction breastfeeding on postpartum mothers at health centers Trenggalek Dongko after breast care entirely, namely 6 respondents $(100 \%)$ of its milk production to normal.

$\mathrm{P}$ roduction breastfeeding on postpartum mother in health center massage Dongko Trenggalek after oxytocin wholly ie 6 respondents $(100 \%)$ of its milk production to normal.

$A$ and the effect of early mobilization on breast milk expenditure on post partum mothers in Dongko Health Center Trenggalek Regency where the value of $p=0,000$ where $p<\alpha(0.05)$.

A and the effect of breast care on breast milk expenditure on post partum mothers in Dongko Health Center Trenggalek District where the value of $p=0,000$ where $p<\alpha(0.05)$.

A and the effect of oxytocin massage on breast milk expenditure in post partum mothers in Dongko Health Center Trenggalek Regency where the value of $p=0,000$ where $p<\alpha(0.05)$.

The harmonic mean values produced between treatment groups and control groups are in different subset columns. Massage oxytocin has the highest mean value. This shows that the highest increase in breast milk expenditure in the Dongko Health Center in Trenggalek Regency is the oxytocin massage treatment.

\section{REFERENCES}

Ambarwati, Retna, E., \& Wulandari, D. (2015). Asuhan Kebidanan Nifas. Yogyakarta: Nuha Medika. Bobak, \& Lowdermilk. (2015). Buku Ajar Keperawatan Maternitas. Jakarta: EGC.

Clark. et al. (2013). Panduan Praktis Keperawatan Dasar. Jakarta: EGC.

Chapman. (2016). Persalinan dan Kelahiran Asuh Kebidanan. Jakarta: EGC.

Depkes RI. (2016). Manajemen Laktasi. Departemen Kesehatan: Jakarta: Depkes RI.

Dinkes Kab. Trenggalek. (2017). Profile Kesehatan Kabupaten Trenggalek tahun 2016. Trenggalek: Dinkes Kab. Trenggalek.

Dewi, \& Vivian, N., L. (2013). Asuhan Kebidanan pada Ibu Nifas. Jakarta: Salemba Medika.

Diah, W. (2013). Asuhan Kebidanan Nifas. Yogyakarta: Nuha Medika.

Hidayat, A., \& Aziz, A. (2014). Metode Penelitian Kebidanan dan Teknik Analisis Data. Jakarta: Salemba Medika.

Huliana, \& Mellyna. (2013). Perawatan Ibu Pasca Melahirkan. Jakarta: Puspaswara.

Kemkokesra. (2015). Pedoman Perencanaan Program. Gerakan Nasional Percepatan Perbaikan Gizi dalam Rangka Seribu Hari Pertama Kehidupan (Gerakan 1000 HPK). Jakarta.

Manuaba. (2013). Ilmu Kebidanan Pengakit Kandungan dan KB. Jakarta: BPSP.

Nanda. (2016). Diagnosis Keperawatan Definisi \& Klasifikasi 2015-2017 Edisi Revisi. Jakarta: EGC.

Roesli, U. (2013). Panduan Praktis Menyusu. Jakarta: Sentra Laktasi Indonesia.

Saleha, \& Sitti. (2015). Asuhan Kebidanan Pada Masa Nifas. Jakarta: Salemba Medika 